\section{Model for comprehensive management of patients and family members with noncommunicable diseases.}

\section{Tania Ivette Domínguez-Isidro 1 Crystell Guadalupe Guzmán-Priego ${ }^{1}$ Juan Antonio Córdova-Hernández ${ }^{1}$ David Del Valle-Laveaga ${ }^{1}$ Juan Manuel Muñoz-Cano ${ }^{1}$}

1Universidad Juárez Autónoma de Tabasco

Contacto: juan.munoz@ujat.mx

DOI:https://doi.org/10.19136/mhr.a6n1.4467

\begin{abstract}
Introduction. Non-communicable diseases associated with diet are preventable and manageable with comprehensive pharmacological and nonpharmacological treatment. However, in Tabasco, as in Mexico, and many countries, these diseases increase in prevalence, as well as the severity of their complications and increase the lability of patients to others such as covid-19, in a syndemic. This is why projects are needed to promote this comprehensive care. Methods. It is a descriptive, cross-sectional investigation for the elaboration of the strategic planning of a High Specialty Hospital oriented to noncommunicable diseases. A diagnosis was made in a first stage from which a proposal was elaborated. Results. The diagnosis showed that medical graduates need to learn how to be leaders to accompany their patients to the achievement of treatment goals. A comprehensive care project was designed. It consists of services for the acceptance of the disease, education for a healthy lifestyle, learning for the selection of dishes and products for sustainability, supported by a collection of videos and podcasts prepared for this project, as well as followup to keep the patients and their families in the service. Indicators were developed according to results. Conclusion. The construction of a comprehensive management of patients to reduce progression, the number of patients and prevent secondary and tertiary organic damage, is a priority for the reconfiguration of services.
\end{abstract}

Keywords. Progression; Prevention; Healthy life style; Social marketing; Leadership 


\section{Resumen}

Introducción. Las enfermedades no transmisibles asociadas a la alimentación son prevenibles y manejables con un tratamiento integral, farmacológico y no farmacológico. Sin embargo, en Tabasco, como en México, y muchos países, estas enfermedades aumentan en prevalencia, así como la gravedad de sus complicaciones y aumentan la labilidad de los pacientes a otras como la covid-19, en una sindemia. Es por esto por lo que se necesitan proyectos que promuevan esta atención integral. Método. Se trata de una investigación descriptiva, transversal, para la elaboración de la planeación estratégica de un Hospital de Alta Especialidad orientado a enfermedades no transmisibles. Se hizo un diagnóstico en una primera etapa a partir del cual se elaboró una propuesta. Resultados. El diagnóstico mostró que los egresados de medicina necesitan aprender cómo ser líderes para acompañar a sus pacientes al logro de las metas del tratamiento. Se diseñó un proyecto de atención integral. Consta de servicios para la aceptación de la enfermedad, educación para el estilo de vida saludable, aprendizaje para la selección de platillos y productos para la sustentabilidad, apoyado por un acervo de videos y podcasts elaborados pare este proyecto, así como seguimiento para mantener a los pacientes y sus familias en el servicio. Se elaboraron indicadores de acuerdo con resultados. Conclusión. La construcción de un manejo integral de los pacientes para disminuir la progresión, la cantidad de pacientes y prevenir de manera secundaria y terciaria daños orgánicos, es prioridad para la reconfiguración de los servicios.

Palabras clave. Progresión; Prevención; Estilo de vida saludable; Mercadotecnia social; Liderazgo
Noncommunicable diseases (NCDs) associated with diet are type 2 diabetes mellitus (DM2), systemic arterial hypertension (SAH), atherosclerosis, chronic kidney disease (CKD), non-alcoholic liver cirrhosis (NASH), cerebrovascular disease, ischemic heart disease, as well as all-cause mortality (Royo, 2020). This is because modern food is based on ultraprocessed foods, which produce low-grade systemic inflammation (Tabung et al, 2026; 2017).

For DM2, data from the 2012 National Nutrition and Health Survey showed that $9.2 \%$ of the population had this disease, corresponding to 6.4 million people over 20 years of age. In 2018, the survey data showed an increase of $10.3 \%$ equivalent to 8.6 million people, 2.4 million more than in 2012 (ENSANUT, 2018). In 2012 there were 84,902 deaths from DM2, which led the Ministry of Health to issue an epidemiological alert in 2016 (Salud, 2016). Overall, in Mexico, premature mortality due to NCDs increased by $206 \%$ between 2007 and 2017 (IHMT, 2018). On the other hand, NCDs syndemically increase the population's lability to other diseases such as Covid19. In this way, when people with NCDs fall ill with Covid-19, they are more likely to develop a serious condition due to the "cytokine syndrome" (Amezcua, 2020).

One of the consequences with the greatest economic impact in chronic kidney disease that mainly affects patients with DM2 and SAH (Rodríguez et al, 2010). An incidence of patients with chronic kidney disease (CKD) is estimated at 377 cases per million inhabitants and the prevalence of 1,142; It has around 52,000 patients in substitution therapy, of which $80 \%$ of the patients are treated at the Mexican Institute of Social Security (IMSS). The cost applicable to 2020 was $\$ 131.00$ Mexican pesos per dialysis session, and $\$ 4,857.00$ per hemodialysis session. Therefore, the estimated annual investment per patient with CKD is $\$ 75,827.00$ (IMSS, 2019). In Mexico, the NCD pandemic also affects health professionals. At the beginning of the spread of Covid19 in Mexico, a significant number of health personnel had to be licensed due to being over 65 years old, but also due to the prevalence of NCDs among them. Thus, the Social Security and Services Institute for state workers (ISSSTE) lost $43 \%$ of its health employees (GM, 2020), and the Mexican Social Security Institute up to $30 \%$ due to risk factors, older age to 65 years and ENT (IMSS, 2020).

In contrast, poorly processed foods are less likely to develop NCDs. Evidence shows that consumption 
patterns based on these foods, such as vegetariantype foods, are associated with better metabolic control (Quiles \& Portolés, 2013), and free people from the need to count calories (ADA, 2016). In this context, the traditional ethnic diets that are associated with a lower risk of developing DM2 are those that have a high proportion of fresh vegetables, such as the Mediterranean (Buckland et al, 2008) and the Japanese from the island of Okinawa. Regarding Tabasco, some studies show important differences in clinical chemistry indicators between those who consume modern diets or traditional diets (Muñoz, 2013; 2014; 2016).

Healthy diets such as those described above are part of the non-pharmacological management of dietrelated NCDs. In Mexico there are Clinical Practice Guidelines "evidence and recommendations" IMSS718-14 (2014) and "quick reference" IMSS-718-14 (2014) where the action protocol for patients with DM2 is explicit and describe the needs of nonpharmacological treatment and emphasis is placed on its implementation as a condition for the metabolic control of patients. Based on this concept, health communication guides have been designed in Mexico with the aim of promoting non-pharmacological treatment of patients with Type 2 Diabetes Mellitus. These are part of the Diabetes Mellitus Action Program of the Ministry of Health, specifically the PrevenIMSS and DiabetIMSS of the Mexican Institute of Social Security (Gil et al, 2013). However, either because they do not integrate other approaches in addition to the pharmacological ones to high specialty care, or because it is not considered to modify the usual approach of the nutritional consultation, the results do not show significant progress in the modification of the medical performance indicators. In this context, the objective of this work is to prepare a proposal for the prevention and control of NCDs associated with food based on the methodology of strategic planning.

\section{Method}

The work was carried out in two stages. The first diagnostic and the second propositional. In the first stage, a study was carried out to support the development of a program for the comprehensive care of patients with NCDs and their families who are cared for in the third-level hospital studied. In the second part, a proposal was developed for care from various disciplinary approaches that must be integrated into a service for the comprehensive care of patients.

Diagnostic stage. To substantiate a proposal, an environmental analysis was made by evaluating the strengths and weaknesses (SWOT) of the institution in different key aspects such as the social environment and the processes of product generation, its structure, resources and culture. The literature was reviewed about the capacities of medical graduates to promote healthy eating and observations of the usual practices in the management of these patients, since the doctor must be able to lead the nutritional management of patients in coordination with the nutrition departments and specialists (ADA, 2019). Based on the literature regarding the practices of caring for patients with NCDs in this environment, an Ishikawa diagram was made. Proposal stage. In the second stage, a comprehensive care proposal was developed. This proposal was made based on the approaches of the different disciplines from which these patients are cared for. The proposal was made in order to integrate these approaches into an interdisciplinary care module. It was considered that medical health workers who habitually evaluate patients from the perspective of relating drugs and anthropometric and clinical chemistry parameters have to integrate other data, the result of psychological and nutritional evaluations, and provide indications for follow-up and education of patients and their families. It is also necessary that, as part of medical education and in health sciences, social service providers are integrated into these units.

\section{Ethical considerations}

The study adhered to the provisions of the Regulations of the General Health Law on research for health, Article No. 17, Paragraph I and Article 23 of Chapter I on the ethical aspects of the Research. It complies with the content of the Declaration of Helsinki.

\section{Results}

Preparation of the diagnosis

1. SWOT analysis. Evaluation of internal factors. Although there are personnel with specialties and subspecialties, which supports the quality of services, there is not enough material and equipment to carry 
out the tests that patients require to evaluate their adherence to treatments or to make more accurate diagnoses in In less time, the fragmentation of services, which produces a lack of coordination between them, is an obstacle for the comprehensive management of patients, in addition to the need for greater capacity for non-pharmacological management of non-communicable diseases. The evaluation of external factors showed the high prevalence of non-communicable diseases, especially those associated with food, since they depend on the offer that the food and beverage industry makes through marketing processes, they saturate the services, especially because the patients develop multiple organic deterioration due to the progression of the initial disease (Figure 1, Table 1).

Table 1

SWOT analysis

\begin{tabular}{|c|c|}
\hline Threats & Opportunities \\
\hline \multirow[t]{2}{*}{$\begin{array}{l}\text { High prevalence of } \\
\text { patients with } \\
\text { noncommunicable diet- } \\
\text { dependent diseases } \\
\text { such as diabetes } \\
\text { mellitus, hypertension, } \\
\text { chronic kidney disease, } \\
\text { cardiovascular disease, } \\
\text { especially in advanced } \\
\text { stages of disease }\end{array}$} & $\begin{array}{l}\text { Develop education } \\
\text { processes } \\
\text { comprehensive } \\
\text { patient management } \\
\text { so that the doctor is } \\
\text { the leader in the } \\
\text { promotion } \\
\text { prevention of organic } \\
\text { damage consistent } \\
\text { with the original } \\
\text { disease }\end{array}$ \\
\hline & $\begin{array}{l}\text { Conduct strategic } \\
\text { hospital programs } \\
\text { according to the } \\
\text { medical need of the } \\
\text { state population }\end{array}$ \\
\hline Strengths & Weaknesses \\
\hline $\begin{array}{l}\text { It has a plant of highly } \\
\text { qualified specialists in } \\
\text { the field of } \\
\text { noncommunicable } \\
\text { diseases, as well as a } \\
\text { nutrition department. }\end{array}$ & $\begin{array}{l}\text { Staff specializing in the } \\
\text { design and } \\
\text { implementation of } \\
\text { educational projects } \\
\text { focused on learning } \\
\text { are lacking }\end{array}$ \\
\hline Quality and value care & $\begin{array}{l}\text { Lack of organizational } \\
\text { culture and assertive } \\
\text { leadership. }\end{array}$ \\
\hline $\begin{array}{l}\text { Continuous updating of } \\
\text { protocols and } \\
\text { procedures }\end{array}$ & $\begin{array}{lr}\text { Lack of coordination } \\
\text { between } \\
\text { specialty departments }\end{array}$ \\
\hline
\end{tabular}

2. Determination of capacities to promote healthy eating. Two studies carried out with medical school students and graduates were reviewed. In the one carried out with students, it was found that for many of the questions the average of the responses was less than $50 \%$ (Salem et al, 2015). In the second one, carried out with doctors in service, who graduated from medical school five years before the survey, poorer results were found with 64.96 average points out of 113 possible (Muñoz et al, 2020).

3. Practices of the medical care of patients with NCDs. Data were found in the scientific literature showing the results of routine care with NCDs patients in a family medicine clinic. Although it is a single clinic so the number of patients is low, it shows the need for better metabolic control. In this sample, no association was found between time of attendance at medical services and improvement in anthropometric parameters. The patients, women and men, were found to be above the cut-off limit of the waist-height index, which measures abdominal adiposity. Nor was an association found between time of attendance and improvement in biochemical markers. The average of glycemia and lipemia was observed to the right of the desirable limit for these. No decrease was found in the use of medications or in their doses. What was observed was the use of acetylsalicylic acid in these patients as a means of preventing acute myocardial ischemia, which shows the effect of drugs on lowering blood glucose and lipemia, among other markers. In these patients, deterioration of glomerular filtration was found, some of them with indicators of chronic kidney disease (Ruiz, 2020).

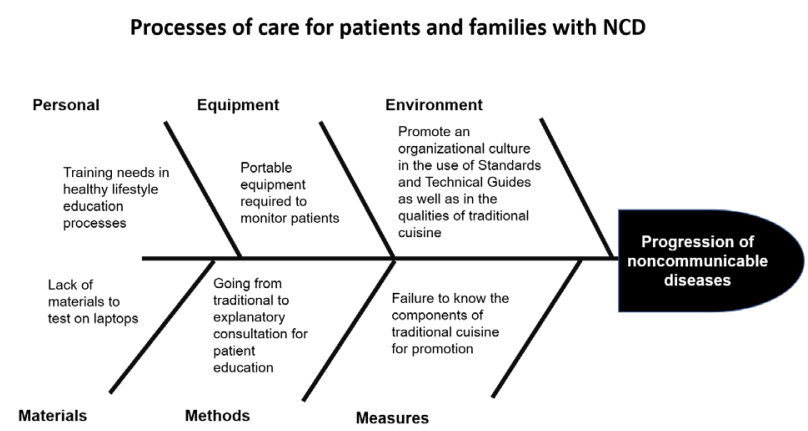

Figure 1. Ishikawa Scheme 
Elements of the proposal (Figure 2)

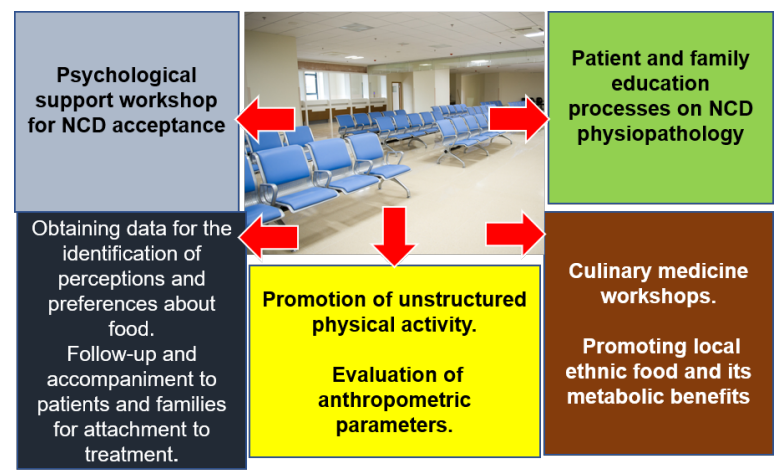

invite students from the schools of psychology of the different universities that teach them.

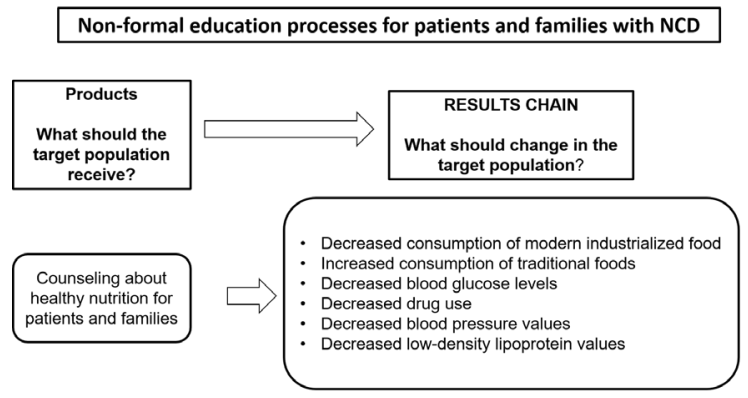

Figure 3. Logical model of the healthy eating promotion project.

Figure 2. Elements of the proposal space

1. Preparation of a database of Hospital patients who require comprehensive management due to NCDs. The anthropometric type should be established in the database, as well as those that express modifications in metabolic processes. These are data that must be monitored to assess whether lifestyle changes affect metabolism or other types of treatment are required.

2. Preparation of a database about the preferences in the selection of foods of the patients. This is necessary to empower patients to achieve modifications in food selection and also in the appropriation of more sustainable consumption styles. The initial data should identify the areas of opportunity for gradual changes in food consumption and its substitution by preferably local ones, and dishes of local ethnic origin.

3. Establish a space where educational work can be carried out with patients. The techniques to carry out this process are those of health communication are the basis for the elaboration of methodological guides and manuals. These activities must be carried out with the patients and at least one member of their family since they have to move together to a healthy lifestyle. Nutrition students are required to be invited to the universities where these educational programs are developed (Figure 3).

4. Develop strategies for the acceptance of NCDs by patients and their families. Patients and their families need to accept that they have a chronic disease, which progresses to deterioration in patients. It is necessary to have the support of psychology professionals, in the manner of grieveing, so you can
5. Space where demonstrative classes for food selection and preparation can be held. It is desirable that the preferences of patients and their families be considered, especially to achieve acceptance of modifications in food consumption, preparation of dishes, and the participation of immediate family members.

6. Preparation of supporting information. Build a collection of podcasts and videos about healthy eating and its preparation. Provide patients with links to guidance texts on food preparation.

7. Develop a digital strategy for the accompaniment of patients and their families through social networks. For this, a survey has to be prepared that patients can answer through their smartphones. These surveys can be made in Google forms to answer from Monday to Friday. The responses are graphed automatically and it is also possible to determine which patients require other monitoring strategies.

8. Follow-up of the proposal. 3 units of observation and analysis were identified a) The target population or people in whom it is expected to observe the change in the results. $b$ ) The point of service which is the physical place where the product is finished organizing and delivered. c) The budget executing unit: they are the administrators of most of the resources (Table 2).

\section{Discussion}

This project is based on the fact that patients with NCDs, as in the case of DM2, lack metabolic control and therefore progress to cardiovascular and kidney complications. This failure is due to at least three factors that make the physician the leader in health 
teams. 1. Lack of ability to prescribe the elements of a healthy lifestyle and goals for their achievement. 2. Ignorance of the imperative need to achieve euglycemia or normotension with nonpharmacological treatment rather than the emphasis on drugs. 3. Lack of competencies for patient education.

Table 2.

Objectives and goals

\begin{tabular}{|c|c|}
\hline Objectives & $\begin{array}{l}\text { Goals (units of } \\
\text { measure) }\end{array}$ \\
\hline $\begin{array}{l}\text { Disseminating the } \\
\text { existence of a public } \\
\text { service }\end{array}$ & Number of registrations \\
\hline $\begin{array}{l}\text { Improving service } \\
\text { experiences }\end{array}$ & Satisfaction surveys \\
\hline $\begin{array}{l}\text { Promoting patient and } \\
\text { family involvement }\end{array}$ & $\begin{array}{l}\text { Number of people } \\
\text { staying in the service }\end{array}$ \\
\hline Foster healthy habits & $\begin{array}{l}\text { Degree of change in } \\
\text { variables }\end{array}$ \\
\hline $\begin{array}{l}\text { Encouraging pride of } \\
\text { belonging }\end{array}$ & $\begin{array}{l}\text { Workplace climate } \\
\text { surveys }\end{array}$ \\
\hline
\end{tabular}

1. Lack of ability to prescribe the elements of a healthy lifestyle and goals for their achievement. 2. Ignorance of the imperative need to achieve euglycemia or normotension with non-pharmacological treatment rather than the emphasis on drugs. 3. Lack of competencies for patient education.

1. Establish a space where educational work can be carried out with patients. For the ADA Guide, nonpharmacological management is of such relevance that the one chapter of the Guide is called "Prevention and delay of type 2 diabetes" (2019, p. S29). For this, medical school graduates would need to have competencies to be leaders of health teams in this sense, which is not the case (Salen et al, 2015; Wynn et al, 2010). Unfortunately, in the traditional medicinal school these capacities are not built (Muñoz et al, 2020; Casanueva \& Valdéz, 1991). Health communication "encompasses the study and use of communication strategies to inform and influence individual and communal decisions that improve health" (U.S. National Institute of Health [USNIH], 2010: p. 2). The recommendations must have a strong local component, therefore the characteristics of the social and cultural environment must be identified in order to provide the program with a strong regional cultural component.

2. Develop strategies for the acceptance of NCDs by patients and their families. Acceptance of NCDs is essential for the implementation of actions for the management of patients who are diagnosed, regardless of their economic level or social status. For the acceptance of NCDs, patients go through the stages described for grief due to the loss of peers, resources, and opportunities. For DM2, there is an Instrument to measure stages of grief in patients with diabetes, which explore the five stages of the Kübler Ross model: denial, anger / disbelief, negotiation, depression and acceptance (Rodríguez et al, 2015).

3. Workshops for demonstration class activities for food selection and preparation. In the 2017 version of the World Medical Association, known colloquially as Hippocrates' Oath, the management of a healthy lifestyle by those who graduate from medical schools is explicit. Upon entering the profession, you swear: "TO CARE for my own health, well-being, and abilities to provide top-level medical care;" (Parsa, 2017). This must have a strong cultural content (La Puma, 2016; Torres, 2004) to make the instructions regain an awareness of belonging and social pride (Table 3).

4. Preparation of information for educational processes. The elaboration of goals to evaluate and re-educate patients in new food concepts that go beyond the simple counting of calories and focus on the type of food, how it is prepared and with what elements, especially in the abandonment of food from animal origin, is a determining factor in the acceptance of the change in lifestyle (Willet et al, 2019; Mozafarian, 2017a; 2017b). The education of patients and their families should be an imperative in medical schools, both through face-to-face demonstrations as well as in videos that are distributed on social networks (Medscape, 2018). For this, patients should be provided with links to guidance texts on the preparation of food with scientific support, such as "Cocina choca, comida sabrosa y sana" (Muñoz et al, 2011). On the other hand, emphasis is required on the measurement of unstructured physical activity as essential for achieving the necessary minimum of minutes per week, since most people do not have access to parks and less frecuently to gyms and swimming pools.

5. Follow-up of the proposal. For patients and their families to strengthen the bond with the health team 
and the doctor-patient relationship, it is necessary to maintain contact with them. This allows to assess the improvement of metabolic goals and anthropometric variables. But it is necessary that the activities of different disciplines be integrated to optimize the control of patients with NCDs (León et al, 2018).

\section{Table 3}

Technical aspects of the product and expectations of the attendees

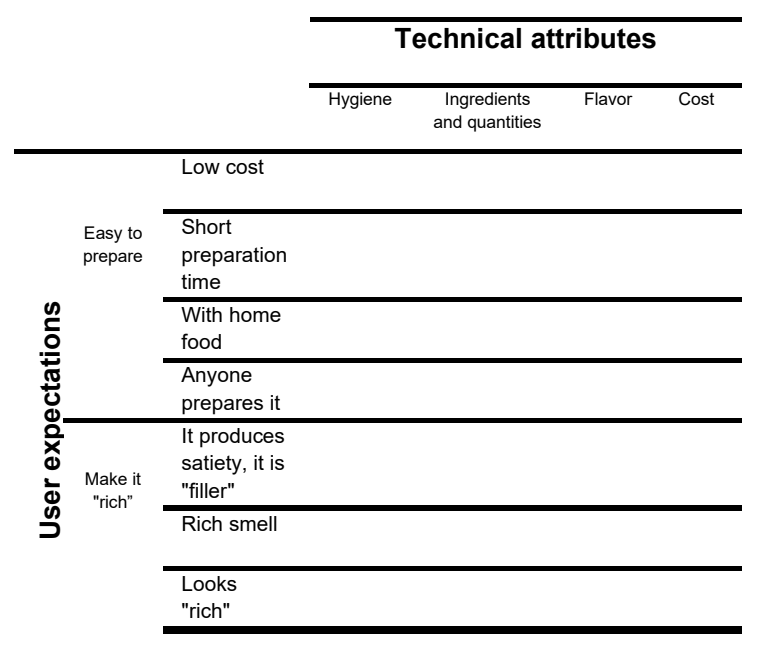

06. Establishment of indicators according to a Results Oriented Budget Program (PPoR). The PPoRs have "the purpose of achieving results on the target population and their environment, based on scientific evidence from specialized literature, and are multisectoral and intergovernmental in nature" (Luna, 2020). For this reason, the indicators are necessary to evaluate the project, those necessary to demonstrate the achievements of the intervention must be measured (Measure Evaluation, 2009). Indicators are instruments that allow the identification of barriers and problems in management and implementation, which is why they are found in an accessible way in the causal chain of strategic planning. Therefore, for this project, indicators of processes, products and results must be measured (IBRD, 2004). For the category of results corresponding to the target population or people in whom changes are expected, the following were selected: Number of patients with decrease in body mass as a function of time. Number of patients with euglycemia without increasing the dose or quantity of drugs. Number of patients with diastolic and systolic pressure at desirable values. Number of patients with a desirable glomerular filtration rate.

\section{Conclusion}

Despite epidemiological alerts, care programs, specialized medical units, and third-level services oriented to NCDs, the prevalence of these increases, as well as the progression to cardiovascular, renal and neurological damage.

The cost of care for patients who progress in their disease is high, and given the conditions of dismantling of the sector, it is unlikely that it can be met in the public service.

The fragmentation of the services, which produces a lack of coordination between them, is an obstacle to the comprehensive management of patients, in addition to the need for greater capacity for nonpharmacological management of these diseases.

The construction of an integral management of patients to reduce the progression, the amount of and prevent secondary and tertiary organic damage, is a priority for the reconfiguration of services.

\section{References}

American Diabetes Association. (2019). Standards of Medical Care in Diabetes. Diabetes Care; 39(S1). https://doi.org/10.2337/dc20-Sint

American Diabetes Association. (01/21/2016). Novedosa campaña de anuncios de servicio público está dirigida a los 86 millones de adultos estadounidenses con prediabetes. http://www.diabetes.org/es/sala-deprensa/comunicados-de-prensa/2016/novedosacampana-de-anuncios-de-servicio-publico-estadirigida-a-los-86-millones-de-adultosestadounidenses-conprediabetes.html?loc=news_ad-councilesp_jan2016.

Amezcua-Guerra, L. M. (2020). Anotaciones breves sobre el síndrome de liberación de citocinas y el bloqueo terapéutico de la interleucina-6 en SARSCoV-2/COVID-19. Cardiovascular and Metabolic Science, $\quad 31(3), \quad 255-258$. 10.24875/ACM.M20000067

Banco Internacional de Reconstrucción y Fomento, Banco Mundial. (2004). Seguimiento y Evaluación - Instrumentos, métodos y enfoques. Washington http://documentos.bancomundial.org/curated/es/24 
0521468336082184/pdf/246140REVISED010eval uation01PUBLIC1.pdf

Barrientos-Cabezas, Á., Arriagada-Pérez, L., Navarro-Vera, G., \& Troncoso-Pantoja, C. A. (2020). Intervención multidisciplinaria como estrategia de aprendizaje en salud. FEM: Revista de la Fundación Educación Médica, 23(2), 69-73.

Buckland, G, Bach, Faig A, Serra-Majem L. (2008). Eficacia de la dieta mediterránea en la prevención de la obesidad. Una revisión de la bibliografía. Revista Española de Obesidad, 6(6):329-39.

Casanueva, E, y Valdéz, R. (1991). El conocimiento nutriológico de médicos residentes. Revista de Investigación Clinica, 43:211-214.

Comité de Planeación para el Desarrollo del Estado de Tabasco. (2019). Programa sectorial salud, seguridad y asistencia social, 2019-2024. Tabasco. https://tabasco.gob.mx/sites/default/files/users/pla neacion_spf/5.\%20Programa\%20Sectorial\%20Sal ud $\% 20 y \% 20$ Asistencia $\% 20 \% 20$ Social.pdf

Dos Santos, B. (2020). La cruel pedagogía del virus. CLACSO.

Instituto Nacional de Salud Pública. (2018). Encuesta Nacional de Salud y Nutrición. https://ensanut.insp.mx/

Institute of Health Metrics and Evaluation. (2018). México.

http://www.healthdata.org/mexico?language $=149$

Instituto Mexicano del Seguro Social. (28 de noviembre de 2019). Secretaría General. Ciudad de México.

https://www.dof.gob.mx/nota_detalle.php?codigo= 5583111\&fecha $=30 / 12 / 2019 \&$ print=true

Gil-Velázquez, L. E., Sil-Acosta, M. J., AguilarSánchez, L., Echevarría-Zuno, S., MichausRomero, F., \& Torres-Arreola, L.P. (2013). Perspectiva de la diabetes mellitus tipo 2 en el Instituto Mexicano del Seguro Social. Revista Médica del Instituto Mexicano del Seguro Social, 51(1),58-67.

Gobierno de México. (28 de agosto de 2020). Informe diario de la pandemia de covid-19 en México.

La Puma, J. (2016). What is culinary medicine and what does it do? Population health management, 19(1), 1-3. 10.1089 / pop.2015.0003

León-Sierra, L. P., Jiménez-Rodríguez, C., CoronadoTovar, J. J., Rodríguez-Malagón, N., \& Pinilla-Roa, A. E. (2019). Evaluación y seguimiento de pacientes ambulatorios con diabetes mellitus tipo 2 mediante control metabólico individualizado y variables antropométricas. Revista Colombiana de
Cardiología, 26(4), 236-243. https://doi.org/10.1016/j.rccar.2018.12.004

Luna-Ortiz, P., Flores-Chávez, P. L., Guarner-Lans, V., Machado-Diaz, A. M., Olivares-Sanromán, M. E., y Martínez-Rosas, M. (2015). La memoria metabólica y las complicaciones cardiovasculares en el paciente diabético. Revista Mexicana de Anestesiología, 38(4), 249-263.

Measure Evaluation. (2009). Fundamentos de Monitoreo y Evaluación. MS-07-ES.

Medscape. (2018). The Doctor will feed you now; culinary medicine. https://www.facebook.com/30664024188/videos/1 0156155219959189

Mozaffarian, D (2017). Foods, obesity, and diabetes-are all calories created equal? Nutrition reviews, 75(suppl_1), 19-31. 10.1093 / nutrit / nuw024

Muñoz Cano, J. M. (2011). Cocina tradicional tabasqueña: Componentes bioactivos, alimentos funcionales. Universidad Juárez Autónoma de Tabasco.

Muñoz-Cano, J.M., Guzmán, C.G., \& CórdovaHernández, J. (2020). Conocimientos básicos acerca de alimentación saludable en egresados de medicina. Nutrición Hospitalaria, 37(6):1226-1231. http://dx.doi.org/10.20960/nh.03168

Muñoz-Cano, J.M., Carrillo-Aguilar, A., \& CórdovaHernández, J. (2013). Lipid-lowering effect of maize-based traditional Mexican food on a metabolic syndrome model in rats. Lipids Health and $\quad$ Disease, 35. http://www.lipidworld.com/content/12/1/35

Muñoz-Cano, J. M., Díaz, A., Alamilla, C. J., Caballero, D., \& Pool, J. (2014). Effect of Eating Oreochromis aureus on Biochemical Markers in Young People. Journal of Nutrition \& Food Sciences, 4(4), 1. 0.4172/2155-9600.1000283

Muñoz-Cano, J. M., Córdova, J., Boldo, X., \& del Valle Laveaga, D. (2016). HOMA-IR anomalies and sugar consumption in young with euglycemia. Pakistan Journal of Nutrition, 15(1), 52-57. 10.3923 / pjn.2016.52.57

Quiles L, Portolés O, Sorlí JV, Miquel M, \& Corella, D. (2013). Efectos a corto plazo en la pérdida de peso de una dieta vegetariana baja en grasa. Nutrición Clínica y Dietética Hospitalaria, 33(3),58-67. 10.12873/333lowfatvegetarian

Tabung, F. K., Smith-Warner, S. A., Chavarro, J. E., Wu, K., Fuchs, C. S., Hu, F. B., \& Giovannucci, E. L. (2016). Development and validation of an 
Empirical Dietary Inflammatory Index-3. The Journal of Nutrition, 146(8), 1560-1570. https://doi.org/10.3945/jn.115.228718

Torres, G. F., Madrid, L., \& Santoni, M. (2004). El alimento, la cocina étnica, la gastronomía nacional. Elemento patrimonial y un referente de la identidad cultural. Scripta Ethnologica, 26, 55-65. https://ri.conicet.gov.ar/handle/11336/98744

Parsa-Parsi, RW. (2017). The revised Declaration of Geneva: a modern-day physician's pledge. JAMA, 318(20), 1971-1972. 10.1001 / jama.2017.16230

Rodríguez-Moctezuma, J. R., López-Delgado, M. E., Ortíz-Aguirre, A. R., Jiménez-Luna, J., LópezOcaña, L. R., \& Chacón-Sánchez, J. (2015). Stages of grief in diabetes and metabolic control. Revista Médica del Instituto Mexicano del Seguro Social, 53(5), 546-551.

Royo-Bordonada, M. Á., Rodríguez-Artalejo, F., BesRastrollo, M., Fernández-Escobar, C., González, C. A., Rivas, F., \& Navarro, C. (2020). Políticas alimentarias para prevenir la obesidad y las principales enfermedades no transmisibles en España: querer es poder. Gaceta Sanitaria, 33, 584-592.

http://dx.doi.org/10.1016/j.gaceta.2019.05.009

Rodríguez Bolaños, R. D. L. Á., Reynales Shigematsu, L. M., Jiménez Ruíz, J. A., Juárez Márquezy, S. A., \& Hernández Ávila, M. (2010). Costos directos de atención médica en pacientes con diabetes mellitus tipo 2 en México: análisis de microcosteo. Revista Panamericana de Salud Pública, 28, 412-420.

Ruiz Cruz, Y. V. (2020). Riesgo de enfermedad cardiovascular y enfermedad renal en asistentes a la clínica 43 del IMSS de Villahermosa, Tabasco, en el primer semestre de 2019. Un estudio transversal. Tesis de licenciatura en médico cirujano. Universidad Juárez Autónoma de Tabasco.

Secretaría de Salud de México. (11/14/2016). Emite la Secretaría de Salud emergencia epidemiológica por diabetes mellitus y obesidad. https://www.gob.mx/salud/prensa/emite-lasecretaria-de-salud-emergencia-epidemiologicapor-diabetes-mellitus-y-obesidad

Salem-Oramas, C. E., Córdova-Hernández, J. A., \& Muñoz-Cano, J. M. (2015). Educación médica y nutrición: estudio acerca de las capacidades para la promoción de la alimentación saludable. Nutrición Clínica y Dietética Hospitalaria, 35, 59-65. 10.12873/353salem
Tabung, F. K., Smith-Warner, S. A., Chavarro, J. E., Fung, T. T., Hu, F. B., Willett, W. C., \& Giovannucci, E. L. (2017). An empirical dietary inflammatory pattern score enhances prediction of circulating inflammatory biomarkers in adults. The Journal of Nutrition, 147(8), 1567-1577. 10.3945/jn.117.248377

US National Institute of Health. (2010). Making Health Communications Programs Work. http://www.cancer.gov/cancertopics/cancerlibrary/p inkbook/Pink_Book.pdf .

Willett, W., Rockström, J., Loken, B., Springmann, M., Lang, T., Vermeulen, S., \& Jonell, M. (2019). Food in the Anthropocene: the EAT-Lancet Commission on healthy diets from sustainable food systems. The Lancet,393(10170):447-492. https://doi.org/10.1016/S0140-6736(18)31788-4

Wynn, K., Trudeau, J. D., Taunton, K., Gowans, M., \& Scott, I. (2010). Nutrition in primary care: current practices, attitudes, and barriers. Canadian Family Physician, 56(3), e109

Received:2021-03-03

Accepted: 2021-08-17 